\title{
Abstinence-Only Sex Education: A Missing Yet Crucial Topic in Digital Media
}

\author{
Esther Idayanti ${ }^{1},{ }^{*}$ Lely Natalia ${ }^{2}$ \\ ${ }^{1,2}$ Sekolah Tinggi International Harvest, Tangerang, Indonesia \\ *Corresponding author.Email: estheridayanti@ hits.ac.id
}

\begin{abstract}
Premarital sex is becoming a major issue for teens in Indonesia. The number of teens involved in premarital sex continues to rise. This behavior has brought problems such as HIV/AIDS, teen pregnancy, as well as family and psychological problems. Premarital sex results in deep emotional disturbances such as anxiety, stress, and depression, especially in a nation that upholds religious values such as Indonesia. This presents great challenges in achieving the sustainable development goals of good health and well-being, and it hinders the attempt to involve the next generation in building sustainability. Currently, the sex education available in the media is run by influencers who endorse the enjoyment of sex before marriage. This paper will discuss the problems with the current sex education in Indonesia. The research employs a literature study, using journal articles, books $s_{2}$ and other publications such as a manual from the United Nations to present the case, along with a media search to provide the background information on sex education in Indonesian media. The findings of this research emphasize the need to provide abstinence-based sex education according to values and character in a digital platform, specifically targeted to young people in Indonesia.
\end{abstract}

Keywords: abstinence, online sex education, premarital sex, sex education, teen sexuality

\section{INTRODUCTION}

She claimed herself to be a sex educator with more than 25,000 followers on her Instagram account. Sisil, a sex educator, conducted the webinar "Sex Education" from her bedroom wearing lingerie while answering the questions of the participants who were single like her. The questions ranged from where to get tested for sexually transmitted diseases (STDs) to how to know whether a person's boyfriend truly loved her or just used her for sex. The sex educator also explained in detail how to achieve satisfaction during sex and shared information about sex toys. This webinar was not conducted by a Western (American or European) individual where premarital sex is accepted as the norm, but it was conducted in Indonesia, where premarital sex is condoned by religion [1]. However, she is not the only one; many sex educators give free advice on social media such as Instagram, YouTube, and TikTok, which are easily accessed by youths. Furthermore, there are even young people who freely share their sexual experiences with their partners and post it on YouTube.
Sex educators provide sexually explicit information on the Internet that can be easily accessed by anyone. It emphasizes sexual activity as a personal right and enjoyment, highlighting the use of condoms to avoid STDs and pregnancy. This is from a desktop survey on "sex educators" on Instagram using the taglines \#edukasiseks \#sexeducator, \#edukasiseksremaja, and similar hashtags. However, there is no mention of the importance of abstinence as a healthy and safe alternative. This paper will discuss the importance of providing sex education online which prioritizes abstinence.

\section{METHOD}

This paper was written with an exploratory study using a literature research methodology to access information from various literature sources to examine the topic reviewed [3]. This paper used journal articles, books, and other publications such as a manual from the United Nations. First, it described the young generation and their sexual lifestyles. Second, it explained different sex education approaches and identified the most appropriate method for Indonesia. Third, it described 
youths and their interactions with digital media. Lastly, it suggested some ways in which sexual abstinence education can be promoted for youths in this digital age.

\section{FINDINGS AND DISCUSSION}

\subsection{Youths and Sexuality}

Statistics show that $90 \%$ of elementary school students (grades 4 to 6) have access to pornographic content from the Internet [4]. One of children's first exposures to sex is from the Internet. Currently, premarital sex is becoming the norm in big cities, as numerous teens are already engaging in premarital sex in locations such as Jabodetabek (51\%), Surabaya (54\%), Medan (52\%), and Bandung (47\%) [5]. As a result of having a premarital sex lifestyle, the number of abortions among teens is estimated to be around 800,000 per year [6]. Looking at these statistics, teenagers are engaging in risky sexual behavior that needs to be addressed.

While youths are seeking sex-related information from the media, parents are reluctant to speak about sex to their children [7]. In addition, the government does not provide sex education as needed by teens. Although the Deputy of the Department of Education of Indonesia said that sex education has been included in the curriculum [8], the head of BKKBN (National Family Planning Coordinating Agency) argued that sex education is not the same as the reproduction health science taught in the classroom [9]. Reproduction health science discusses the reproduction organs, how they function, and the stages of embryonic growth in the womb [10]. Sri Wiyanti, the Head of the Legal and Gender Society, stated that the government does not have the courage to implement sex education in a formal education setting because of pressure from certain groups that see sex education as a moral issue, not a need. Hasto, the Head of BKKBN, explained that the perception that sex education will bring more negative impacts than positive impacts has caused a strong opposition to sex education [9]. On one hand, youths are seeking information about sexuality from the Internet, including pornographic materials, but on the other hand, parents and the government are not ready to provide proper sex education because of many cultural and religious restrictions. There is a need to offer sex education for teens that educates and helps them choose a better approach to sexuality. Enabling access to sex education is part of accomplishing the SDG of "good health and well-being". Regardless of the type of sex education, adolescents who receive sex education display more sexually responsible behavior compared to those who do not receive sex education [11].

\subsection{Abstinence-Only Sex Education for a Better Future}

There is continuous debate among educators regarding the best type of sex education: comprehensive or abstinence-only. Abstinence-only sex education emphasizes the importance of delaying sex until marriage and does not offer information on contraceptives for a safer sexual experience. Comprehensive sex education, on the other hand, highlights safe sex by using contraceptives. The proponents of comprehensive sex education argue that abstinence-only sex education does not reduce teen pregnancies. In fact, it is linked with the increasing rate of teen pregnancies [12]. However, the proponents of abstinence-only sex education contend that there are detrimental effects of premarital sex on youths. Some of the negative effects are teenage pregnancy, abortion, HIV/AIDS, and other STDs. More than just affecting their physical health, premarital sex also causes serious emotional and mental damage, such as guilty feelings, a loss of self-respect, depression, substance abuse, and even suicidal thoughts [13]. Premarital sex will also potentially damage future marriage relationships [14]. These ramifications will negatively affect the health and well-being of adolescents, thus deterring the achievement of the third SDG goal, good health and well-being. Consequently, the main purpose of sex education is not only to share information on sexuality, but also to encourage teens to abstain from sex until marriage, which will significantly enhance their health and well-being, both physically and psychologically.

Studies affirm that religious adolescents have more conservative views toward sex and will delay engaging in sexual behavior. Most proponents of comprehensive sexual education are from the United States where teaching religious values at school is unconstitutional [15]. Therefore, they cannot have a solid foundation to teach abstinence-only sex education. On the other hand, Indonesia whose national philosophy is Ketuhanan Yang Maha Esa (belief in God Almighty), has a great advantage in teaching abstinence-only sex education. Although globalization has brought "Western" culture, religion is still an important part of communities and families in Indonesia. Thus, abstinence-only sex education can be taught to prevent youths from engaging in premarital sex.

The United Nations Educational, Scientific, and Cultural Organization (UNFPA) underscores the importance of sexual education beyond knowledge about reproduction and the risks of premarital sex and STDs that are usually presented in negative ways. Adolescents need to learn the positive aspects of sex education such as love, respect, and equality in a relationship. UNFPA even includes topics such as making a long-term commitment and marriage responsibilities [16]. Topics such as respecting others, 
being responsible, and keeping commitments are part of character-building education. Thus, sex education cannot be separated from character building. However, topics such as love, respect, equality, responsibility, and commitment are not covered by the sex educators in social media who focus mainly on sexual enjoyment and intercourse.

\subsection{Youths and the Media}

In the digital era, teens are exposed to abundant information from the Internet and social media. YouTube, TikTok, Instagram, and Twitter are some popular social media sites among Indonesian youths. This media seeks their attention, and at the same time provides opportunities for them to become recipients of information, distributors, content creators, or recyclers of information [17]. This condition has opened many doors for learning opportunities among teens. There is a tendency for young people to sense that digital media offers more interesting content than schools do, thus leading them to ignore their academic activities, while schools belittle digital media trends as a new way of learning [18]. To address the issue of how abstinencebased sex education can be presented for adolescents nowadays, we should consider digital media trends as a new way of learning.

Besides gaining information, teens also use social media to connect with the world and to influence others. Connections and influence are considered as two important factors in the notion of a community [19]. Youths can easily connect themselves to people with common interests and seek information from any sources which catch their attention. More and more teens are inspired to gain followers in their personal social media platforms by becoming influencers. They share and gain information through vlogs, short videos, reels, tweets, social media feeds, blogs, etc. Adolescents nowadays are very adept at using technology to express their creativity or satisfy their curiosity. They like to either influence others or be influenced. As stated in the statistical data presented in the beginning of the discussion, Indonesian youths engage in risky sexual behavior due to negative influences from digital media. Seeing this phenomenon, there is an urgency to provide sexual abstinence education in a digital platform and maximize the movement by involving potential teens and other collaborators to become micro influencers who can promote a sexual abstinence way of life in their social media. Micro influencers are people who have from 5,000 to 10,000 followers on their social media platforms [20]. Collaborators can also be inspiring parents, psychologists, artists, singers, educators, religious leaders, or government officers. These micro influencers can serve as ambassadors of an abstinencebased sex education program.

\subsection{Sex Education in the Digital Era}

Most sex education on social media in an Indonesian setting is given by laypersons who serve as peer sex educators, such as Sisilism on YouTube and Instagram, @janofahchiny, @jenniferelim, and others.

As social media has become the preferred platform for many young people, leading institutions on family and sex education such as BKKBN, Family Planning of Indonesia (Perkumpulan Keluarga Berencana Indonesia/PKBI), or the Education Department of Indonesia who currently implement sex education at school should enter the platform. The latest and fastest growing social media platform is TikTok, and Indonesia was the second largest market for TikTok in 2020 with 22.2 million monthly active users [21]. However, formal sex education organizations are steering away from this platform. They are missing a great opportunity to reach young people and start a discussion with them. Thus, sex education based on abstinence should be present in every digital platform, such as TikTok, Instagram, YouTube, and others.

In addition, a comprehensive digital marketing strategy is needed to make a sexual abstinence education program become a success. Community mobilization can be used as a strategy to mobilize society for long-term change to provide support for the young generation to choose sexual abstinence as a commitment. Community mobilization is defined as an effort to involve the community to address certain issues through an organized movement [22]. Synergy between Indonesian teens, parents, psychologists, educators, educational institutions, the government, and community-based organizations is needed to achieve this goal. This synergy can be united by creating a digital community-based organization which has an account in all popular social media platforms. This organization can be a digital home community for Indonesian youths where they can connect, socialize, learn, influence, seek counsel about healthy relationships, and inspire others to choose a sexual abstinence lifestyle. At the same time, this digital community can also equip teenagers' parents with knowledge about how to teach and apply the values of sexual abstinence-based education in their families through inspiring vlogs, reels, webinars, online counselling, and other social media promotions. This digital community-based organization should facilitate sexual abstinence-based education as its core.

Another study on the concept of global learning indicates that how the young generation uses technology in this digital era is still strongly bound to their selfidentity as well as their social and cultural surroundings. One's self-identity influences the ways in which people learn, connect, and socialize [17]. Along with sexual abstinence-based education, there needs to be education 
for adolescents that can strengthen their identities as Indonesians who uphold divine and moral characteristics, as it is stated in the Indonesian state philosophy (Pancasila). A sexual abstinence education curriculum based on values, traits, and commitments as Indonesian citizens needs to be constructed and applied on a digital platform.

This curriculum must be designed with an aim to inspire Indonesian teens to choose a life of values, character, and commitment that leads them to abstain from sex, keep it for marriage, and make them proud of their decision.

Youths can make the right choice if they have communities and resources that support them [22]. A digital community organization to facilitate sexual abstinence-based education on a digital platform combined with a strong sexual abstinence-based curriculum according to Indonesian values and traits could be a perfect strategy to support Indonesian youngsters to make the right decision about sex, thus helping Indonesia to achieve its sustainable development goals.

\section{CONClusion}

Indonesian youths are engaging in risky sexual behavior due to negative influences and exposure from digital media. On the other hand, parents and the government are not ready to provide proper sex education because of various cultural and religious restrictions. This study suggested a sexual abstinencebased education with the main purpose of encouraging teens to abstain from sex and keep sex for marriage as the suitable sex education for Indonesian culture, which has the national state philosophy of "Ketuhanan yang Maha Esa" (belief in God Almighty). This study also revealed that there is an urgency to provide sexual abstinence-based education in a digital platform. Synergy between Indonesian youngsters, parents, educators, educational institutions, the government, and community-based organizations is needed to achieve this goal. This can be realized by creating a digital community-based organization which has an account in selected popular social media platforms. Along with that, a sexual abstinence education curriculum based on values, characteristics, and commitments as Indonesians needs to be constructed. These combinations could be a perfect strategy to support Indonesian teenagers to make the right decision to abstain from sex and keep sex for marriage, thus helping Indonesia to achieve its sustainable development goals.

\section{REFERENCES}

[1] A. R. Tampenawas and V. Y. Mangantibe, "Tinjauan Etis Kristen Terhadap Seksualitas Di Kalangan Pemuda-Pemudi Gereja," SHAMAYIM J.
Teologi dan Pendidik. Kristiani, vol. 1, no. 1, pp. 1-13, 2020, doi: https://doi.org/10.51615/ sha.v1i1.1.

[2] M. G. Syariful and H. Hasan, "Tinjauan Normatif Etika Seksual dalam Hukum Islam," Siyasatuna, vol. 2, no. 1, pp. 34-47, 2020, [Online]. Available: file://C:/Users/ProBook/Downloads/12517-407031-PB.pdf.

[3] G. Lin, "Higher Education Research MethodologyLiterature Method," International Education Studies, vol. 2, no. 4, pp. 179-181, 2009, doi: 10.5539/ies.v2n4p179.

[4] A. Lukihardianti and W. D. Putri, "90 Persen Anak SD Telah Mengakses Pornografi,” 2016. https://nasional.republika.co.id/berita/nasional/um um/16/07/29/ob26e4359-90-persen-anak-sd-telahmengakses-pornografi. [Accessed Oct. 02, 2021].

[5] I. Risnawati, "Perilaku Seksual Pranikah Pada Remaja," 3rd University Research Colloquium, pp. 343-347, 2016, [Online]. Available: ISSN $2407-$ 9189. [Accessed Oct. 02, 2021]

[6] E. Tamunu, "Pengaruh Pendidikan Kesehatan Tentang Abortus Provocatus Criminalis Terhadap Pengetahuan Remaja Putri di SMK Cokroaminoto Kota Manado." Jurnal Kesehatan Saelmakers Perdana, vol. 1, pp. 79-84, 2018.

[7] R. Zakiyah, Y. S. Prabandari, and A. Triratnawati, "Tabu, Hambatan Budaya Pendidikan Seksualitas Dini pada Anak di Kota Dumai," Berita Kedokteran Masyarkat, vol. 32, no. 9, pp. 323330, 2016.

[8] J. P. Sasongko, "Kemdikbud: Pendidikan Seks Sudah Masuk Kurikulum,” CNN, p. t.p., 2016.

[9] A. Nadhira, K. Nadindya, and R. P. Maheswara, "Keterbukaan Pendidikan Seks di Indonesia: Hambatan dan Implementasi," Economica.id, 2020. https://www.economica.id/2020/09/11/ keterbukaan-pendidikan-seks-di-indonesiahambatan-dan-implementasi/ [Accessed Oct. 02, 2021].

[10] Purnomo, Sujino, Trijoko, and S. Hadisusanto, Biologi kelas XI. Jakarta: Pusat Perbukuan Departemen Pendidikan Nasional, 2009.

[11] L. D. Lindberg and I. Maddow-Zimet, "Consequences of sex education on teen and young adult sexual behaviors and outcomes," Journal or Adolescent Health, vol. 51, no. 4, pp. 332-338, 2012.

[12] D. Carter, "Comprehensive sex education for teens is more effective than abstinence," AJN The American Journal of Nursing, vol. 112, no. 3, p. 15, 2012.

[13] R. B. Shrestha, "Premarital sexual behaviour and its impact on health among adolescents," Journal 
of Healthe Promotion, vol. 7, pp. 43-52, 2019, [Online]. Available: https://doi.org/10.3126/ jhp.v7i0.25496. [Accessed Oct. 02, 2021]

[14] S. Stanley and G. Rhoades, "The Perils of Sowing Your Wild Oats," Psychology Today, pp. 40-42, 2016.

[15] C. Collins, P. Alagiri, T. Summers, and S. F. Morin, "Abstinence only vs. comprehensive sex education: What are the arguments," AIDS Research Institute University of California, pp. 116, 2002.

[16] U. N. Women and UNICEF, International technical guidance on sexuality education: an evidence-informed approach. UNESCO Publishing, 2018.

[17] A. Ünlüsoy and M. J. de Haan, "Expanding the notion of global learning: Turkish-Dutch teens' networked configurations for learning," Frontline Learning Research, vol. 8, no. 2, pp. 109-130, 2020.

[18] A. Bernier and R. H. Fowler, "Teens in a Digital Desert: Digital Media Literacy in an Arizona OST Program.," Afterschool Matters, vol. 33, pp. 5057, 2020.

[19] P. Izquierdo-Iranzo and E. Gallardo-Echenique, "Studygrammers: Learning Influencers," Comunicar Media Education Research Journal, vol. 28, no. 1, 2020.

[20] A. E. Foos, "Teaching Generation Z Social Media Marketing: A Micro-Influencer Project.," Journal of Instructional Pedagogies, vol. 24, 2020.

[21] C. M. Annur, "Indonesia Jadi Pasar Kedua Terbesar TikTok di Dunia pada 2020," Databoks, 2021 [Online] https://databoks.katadata.co.id/ datapublish/2021/09/29/indonesia-jadi-pasarkedua-terbesar-tiktok-di-dunia-pada-2020 [Accessed: Oct. 2, 2021]

[22] S. E. Greenberg, L. Davis, C. Tutt MSW, and M. D. Katcher, "Community mobilization: a community-wide approach to promoting adolescent sexual health," Journal Applied Research on Children Informing Policy Child. Risk, vol. 8, no. 1, p. 7, 2017. 